\title{
Availability of African films
}

Until quite recently, it was difficult to obtain copies of many major works of African cinema, and those that were available were, in general, expensive to purchase. Researchers were thus often obliged to view even key works in archives such as the excellent Cinémathèque Afrique in Paris (www.adpf.asso.fr/cinematheque/index.html) or at the British Film Institute in London (www.bfi.org.uk). However, the DVD revolution of the past few years has resulted in the production of relatively cheap copies of important feature films by both established directors and young and upcoming filmmakers. In the United States, the following distributors have an extensive African catalogue, which is available for purchase on-line: California Newsreel (www.newsreel.org), New Yorker Films (www.newyorkerfilms.com), Kino Films (www.kino.com). In France, the Médiathèque des Trois Mondes (www.cine3mondes.com) has released important work by many African directors from both north and south of the Sahara (other distributors tend to concentrate on Francophone West Africa). In Britain, a small number of African films have long been available for screening at the British Film Institute in London. There are now signs that even mainstream distributors, most notably Artificial Eye, have regained an interest in African cinema, as recent films by Haroun (Abouna), Sissako (Waiting for Happiness, Bamako), Sembene (Moolaadé) and Nacro (The Night of Truth) have gained an automatic release on DVD just a few months after their theatrical release; while the French distributor Pathé brought out in 2004 a box set of four of Souleymane Cissé's feature films. As for Africa itself, access to these films remains a major problem, with the cost of DVDs produced in the West being far beyond the pockets of many Africans.

Of the filmmakers discussed in this volume, a range of their feature films is available from a mixture of the above sources. In some cases, such as that of Sembene, virtually the entire back catalogue is now available, following Médiathèque des Trois Mondes' release of a five-DVD box set (just a few years ago, only three or four of Sembene's films were commercially available). While the more successful films (either commercially or artistically) of directors such as Chahine and Darrell Roodt are marketed by outlets such as Amazon (www.amazon.co.uk; www.amazon.com), the same is not 
uniformly true of their other work. In other cases, such as that of Flora Gomes or Idrissa Ouédraogo, the picture is even more mixed, with a partial selection of films being available from various sources; inexplicably, and scandalously, the one director whose work is currently not available at all is Med Hondo. 
David Murphy and Patrick Williams - 9781526141736 Downloaded from manchesterhive.com at $04 / 26 / 2023$ 12:09:59PM 